\title{
is Research Square \\ Removal of perchlorate by a lab-scale constructed wetland using achira (Canna indica L.)
}

\section{Dongqin Li}

Lingnan Normal University

\section{Haishuo Gao}

South China Agricultural University

\section{Xinyu Du}

South China Agricultural University

Junhao Qin

South China Agricultural University

\section{Huashou Li}

South China Agricultural University

Hongzhi He

South China Agricultural University

Guikui Chen ( $\nabla$ guikuichen@scau.edu.cn )

South China Agricultural University

\section{Research Article}

Keywords: perchlorate, biodegradation, constructed wetland, achira, microorganism

Posted Date: June 9th, 2021

DOl: https://doi.org/10.21203/rs.3.rs-188699/v1

License: (a) (i) This work is licensed under a Creative Commons Attribution 4.0 International License. Read Full License

Version of Record: A version of this preprint was published at Wetlands Ecology and Management on August 30th, 2021. See the published version at https://doi.org/10.1007/s11273-021-09827-3. 


\section{Abstract}

Achira (Canna indica L.) has not yet been tested for its potential in removing perchlorate $\left(\mathrm{ClO}_{4}{ }^{-}\right)$from wastewater. In this study, constructed wetlands with and without achira were used to investigate the removal efficiency and removal mechanism of perchlorate. The results showed that more $\mathrm{ClO}_{4}{ }^{-}$was removed by the wetlands with achira relative to those without. Perchlorate removal in the wetlands without achira decreased with time, whereas perchlorate in the wetlands with achira was stably removed. In terms of $\mathrm{ClO}_{4}{ }^{-}$content, the achira tissues were in the descending order of: leaf $>$ aerial stem $>$ flower or rhizome $>$ root. Perchlorate was concentrated in leaves (more than $55.8 \%$ ) rather than in root (less than $0.67 \%$ ). Mass balance calculation showed that plant uptake accounted for $5.81-7.34 \%$ of initial $\mathrm{ClO}_{4}{ }^{-}$input, while microbial degradation accounted for $29.39-62.48 \%$. The wetlands with achira were favorable for soil microorganism growth and proliferation and in turn $\mathrm{ClO}_{4}{ }^{-}$biodegradation. Furthermore, the effluent $\mathrm{pH}$ increased in achira wetland columns and in turn promoting $\mathrm{ClO}_{4}{ }^{-}$removal. The results indicating that the wetlands with achira promote $\mathrm{ClO}_{4}{ }^{-}$ removal by improving the rhizosphere environment.

\section{Introduction}

Used in such industrial productions as fireworks, rubber, and paint manufacturing, perchlorate has emerged as a contaminant in soil, water, and food. United State Environmental Protection Agency (U.S. EPA) reported that perchlorate concentrations up to $2000 \mathrm{mg} / \mathrm{kg}, 3700 \mathrm{mg} / \mathrm{L}, 120 \mathrm{mg} / \mathrm{L}$, and $811 \mu \mathrm{g} / \mathrm{L}$ have been documented in soil, groundwater, surface water, and drinking water, respectively (U.S. EPA, 2005), as well as airborne particulate matter (Wang et al. 2017). In addition, perchlorate has also been detected in food stuffs, breast milk, baby formulas, soft drinks, and human body fluids (Her et al. 2010; Abt et al. 2016; Zhang et al. 2010; Kirk et al. 2012; Shelor et al. 2012; Calderón er al. 2017). In 2009, the US EPA identified perchlorate as a drinking water contaminant (U.S. EPA. 2019), and the State of California controls the maximum contaminant level of perchlorate at $6 \mu \mathrm{g} / \mathrm{L}$ in drinking water (Xie et al. 2018). This has caused a major concern due to the health effects of perchlorate, which is documented to inhibit iodine uptake by the thyroid gland, decrease thyroid production, and lead to thyroid disease (Abt et al. 2016; Kumarathilaka et al. 2016).

As perchlorate ion $\left(\mathrm{ClO}_{4}{ }^{-}\right)$is of low reactivity and high mobility, it is very stable and persistent in the environment (Sevda et al. 2018). Physico-chemical and biological methods have been used for $\mathrm{ClO}_{4}^{-}$ remediation (Choe et al. 2013; Sevda et al. 2018; Nair et al. 2020). Bioremediation, e.g., perchlorate reduction by perchlorate-reducing bacteria (PRB) or chlorate-reducing bacteria (CRB) to chloride $\left(\mathrm{Cl}^{-}\right)$, has been proven to be more environmentally friendly and economical (Bardiya and Bae 2011).

Phytoremediation is a bioremediation technology where perchlorate is reduced via plant uptake, phytodegradation, and rhizo-degradation (Yifru and Nzengung 2008; Bhaskaran et al. 2013). Plant uptake and phytodegradation are slow processes, whereas rhizo-degradation is rapid. Utilizing dissolved organic carbon as a carbon and energy source, PRB can rapidly reduce perchlorate to nontoxic chloride (Dahan et al. 2017; Yifru and Nzengung 2008). 
Constructed wetlands are established mainly for wastewater treatment (Sehar and Nasser 2019; Abdel-Mohsein et al. 2020). As constructed wetlands are easy for operation and maintenance, environmentally friendly, and efficient, they have been widely used in treating domestic wastewater (Bilgin et al. 2014; Fang et al. 2018), industrial wastewater (Calheiros et al. 2012; de la Varga et al. 2020), and agricultural wastewater (Vymazal and Březinová 2015; Smith et al. 2019).

In a constructed wetland system, plants play an important role in pollutant removal. Plants can bind pollutants on their roots and remove pollutants from the water. In addition, plants can mediate redox transformation of pollutants in their oxygen-rich rhizosphere. Therefore, plant species is an important factor influencing a wetland's performance. Our previous research has demonstrated that achira (Canna indica L.), a wetland species with beautiful flowers, is tolerant to perchlorate stress (He et al. 2013). Therefore, perchloratecontaminated waters might be effectively treated by a constructed wetland using achira.

In this study, the main objectives of this work were to explore perchlorate removal potential of achira in vertical flow constructed wetlands. The selected plant species has not yet been tested for use in treatment of wastewaters containing $\mathrm{ClO}_{4}^{-}$. Furthermore, achira is a beautiful plant with ornamental value, easily reproductive and has the ability to absorb nutrient contaminants. The present work studied the accumulation of $\mathrm{ClO}_{4}{ }^{-}$in soil layer, roots, stem and leaves of achira in order to know the removal mechanism and mobility of $\mathrm{ClO}_{4}^{-}$in constructed wetlands. According to previous reports (Tan et al., 2004b; Seyfferth and Parker, 2008; Yifru and Nzengung, 2008), microbial degradation may play a more important role than plant uptake in $\mathrm{ClO}_{4}^{-}$ degradation in natural wetland system. Thus, microbial populations, $\mathrm{NO}_{3}{ }^{-}$in water which proved as a potential competitive electron acceptor with $\mathrm{ClO}_{4}{ }^{-}$were also discussed. The findings of this study are expected to provide support for high efficient wastewater treatment using constructed wetlands of high ornamental value.

\section{Materials And Methods}

Preparation of constructed wetland columns

Wetland columns were prepared using cylindrical ceramic pots (30 cm height and $26 \mathrm{~cm}$ inner diameter) (Fig. 1). For each pot, there was a side opening at the bottom connected to a tube for effluent collecting. Each pot was first filled with a $5-\mathrm{cm}$ layer of cobble (4 kg/pot) and then a $20-\mathrm{cm}$ layer of soil (8 kg/pot). The cobbles, white 1-3 cm diameter, purchased from Goldstone Powder Materials Co., LTD (China), which had been washed with tap water before use. The soil was collected from the surface layer of a paddy field in the Experimental Farm of the South China Agricultural University, air dry and through $2 \mathrm{~mm}$ sieve before use. The main properties of the soil are shown in Table 1.

Plant species

The wetland plant species, achira, was selected for its large biomass and high tolerance to perchlorate (He et al. 2013). Plants of the same size at their three-leaf stage were collected from a local nursery. The seedlings height were about $10-15 \mathrm{~cm}$.

Experimental details 
Constructed wetland columns with or without plants (achira) were prepared to treat waters containing $0\left(C_{0}\right), 40$ $\left(C_{40}\right)$, or $100 \mathrm{mg} / \mathrm{L}\left(C_{100}\right)$ perchlorate. For the three treatments with achira, two achira seedlings at three-leaf stage were transplanted to each wetland column.

Before the experiment started, the columns were first flooded with $6 \mathrm{~L}$ tap water for 7 days, drained, and let stand for one day. Then, they were fed with $6 \mathrm{~L}$ tap water from the top containing 0,40 , or $100 \mathrm{mg} / \mathrm{L}$ perchlorate. Water was added every day for seven days to compensate for evaporation loss. Then, effluents were collected on the 8th day, and the wetland columns were let Plant and bulk soil samples were collected at the end of the experiment. During the whole experiment (53 days), the 18 wetland columns were sheltered from rain. The properties of the tap water used in the experiment are shown in Table 2.

Sample preparation

The collected effluent samples were stored in plastic bottles and kept in a refrigerator until analysis. The plants including roots were washed with tap water and blotted dry. After plant height, root length, and fresh weights of shoot and root were measured, shoots and roots were dried, ground into powder, and sieved through a 35-mesh $(0.5 \mathrm{~mm})$ sieve. Soil samples were freeze-dried, ground, and homogenized with a 35-mesh $(0.5 \mathrm{~mm})$ stainless steel sieve.

For $\mathrm{ClO}_{4}^{-}$concentration determination, the soil and plant samples were processed as described by $\mathrm{He}$ et al. (2013). Briefly, $2.0 \mathrm{~g}$ of plant powder were added into a 50-mL conical flask with $30 \mathrm{~mL}$ Milli-Q water (Milli-Q Water System, Millipore Corporation, Bedford, MA), shaken at $200 \mathrm{rpm}$ and room temperature for $3 \mathrm{~h}$, and centrifuged at $6000 \mathrm{rpm}$ for $25 \mathrm{~min}$. The supernatant was vacuum filtered through a $0.22 \mu \mathrm{m}$ polyethersulfone filter (Millipore Corp., Bedford, MA) and passed through a pre-conditioned ENVI-18 solid-phase extraction (SPE) cartridge (Supelco, Bellefonte, PA) to remove organic materials. The first $1.0 \mathrm{~mL}$ filtrate is discarded and the remaining aliquots are used for analysis. Soil sample $(5.0 \mathrm{~g})$ was weighed into a $50-\mathrm{mL}$ conical flask with 20 $\mathrm{mL}$ deionized water, shaken at $200 \mathrm{rpm}$ and room temperature for $3 \mathrm{~h}$, and centrifuged at $6000 \mathrm{rpm}$ for $25 \mathrm{~min}$. The supernatant was filtered through a $0.22 \mu \mathrm{m}$ polyethersulfone membrane filter, an OnGuard $\mathrm{H}$ cartridge, and an OnGuard RP successively to remove solid substances, metallic ions, and hydrophobic compounds, respectively.

Perchlorate quantification

Chromatographic column IonPac AG20/AS20 was used at $30^{\circ} \mathrm{C}$, the mobile phase was $30 \mathrm{mM} \mathrm{KOH}$ at 1.0 $\mathrm{mL} / \mathrm{min}$, and the injection volume was $10 \mu \mathrm{L}$. After filtration through a $0.22-\mu \mathrm{m}$ filter, the sample solution was injected into the system. The retention time of $\mathrm{ClO}_{4}{ }^{-}$was $15.5 \mathrm{~min}$. The concentrations of $\mathrm{ClO}_{4}{ }^{-}$in the samples were quantified by external calibration. Standard curves were calculated from injection of 50 to $50,000 \mu \mathrm{g} / \mathrm{L}$ calibration standards. A calibration standard was run along with every 10 samples, while a laboratory reagent blank, a laboratory fortified blank, and a laboratory fortified duplicate were run long with every 20 samples. Based on injection of $10 \mu \mathrm{L}$ injections, the instrument detection limit was $20 \mu \mathrm{g} / \mathrm{L}$. Quality control samples were prepared as the effluent, plant, or soil samples. The mean recovery of $\mathrm{ClO}_{4}{ }^{-}$was $100 \pm 10 \%$.

Enumeration of soil microbial populations 
Populations of culturable bacteria, fungi, and actinomycetes in the rhizosphere samples were estimated using the serial dilution technique. Ten gram soil were mixed with $100 \mathrm{~mL}$ sterile water, shaken for 20 min, let stand for 3-5 min, serially diluted, and plated onto 1/10-strength beef-protein agar (BPA), potato dextrose agar (PDA), and starch nitrate agar (SNA) for enumeration of bacteria, fungi, and actinomycetes, respectively.

Statistics analysis

The experiment adopted a completely randomized design in triplicates. Data were analyzed using the analysis of variance (ANOVA) and Duncan's multiple range tests with SPSS-13 statistical package (SPSS Inc., Chicago, IL, USA) at a significant level of $P<0.05$. Results are presented as mean \pm standard error. Perchlorate removal rate was computed as follows:

\section{Removal rate $=\frac{C_{0} * V_{0}-C_{\mathrm{i}}^{*} V_{\mathrm{i}} * 100 \%}{C_{0} * V_{0}}$}

where $C_{0}$ is the initial perchlorate concentration $(\mathrm{mg} / \mathrm{L}) ; V_{0}$ is the initial volume $(\mathrm{L}) ; C_{\mathrm{i}}$ is perchlorate concentration at day $i(\mathrm{mg} / \mathrm{L})$; and $V_{\mathrm{i}}$ is the volume at day $i(\mathrm{~L})$.

\section{Results And Discussion}

Perchlorate removal by the constructed wetland columns

Differences in perchlorate removal were observed in the different treatments (Fig. 2). In terms of average $\mathrm{ClO}_{4}{ }^{-}$ removal rate, the treatments were in the order of: planted $C_{40}(68.29 \%)>$ planted $C_{100}(52.22 \%)>$ unplanted $C_{40}$ $(48.16 \%)>$ unplanted $C_{100}(35.71 \%)$. For a same perchlorate level in influent, significantly more perchlorate was removed by the planted columns than by the unplanted columns. Furthermore, perchlorate removal in the unplanted columns diminished noticeably with running time. By contrast, perchlorate removal in the planted columns did not show a clear reduction, but increased significantly at the sixth period, being $78.46 \%$ and $55.25 \%$ in the planted columns of $C_{40}$ and $C_{100}$, respectively. In comparison, only $41.52 \%$ and $20.20 \%$ of perchlorate were removed from the influent at day 53 in the unplanted $C_{40}$ and $C_{100}$ columns, respectively.

Tan et al. (2004) also demonstrated that perchlorate removal by wetland columns planted with Bulrush (Scirpus sp.) was higher as compared with columns without plants. Plants are a key component of constructed wetlands and their presence is known to improve pollutant removal (Ballesteros et al. 2016). Plants absorb nutrients, heavy metals, and toxic substances from waters. In addition, they introduce an aerobic root zone and increase aerobic processes as compared with unplanted "wetlands" (Faulwetter et al. 2009). Furthermore, wetland plant roots secrete such substances as enzymes, organic acids, and organic carbon, which are favorable for microbial metabolism, growth, and reproduction (Wu et al. 2017) and subsequently promote perchlorate biodegradation.

Plant uptake 
Plant height, and plant biomass in columns $C_{40}$ and $C_{100}$ were significantly lower as compared with column $C_{0}$ (Table 3), indicating that achira growth was inhibited by $\mathrm{ClO}_{4}^{-}$. However, the results also demonstrated that achira could tolerate high $\mathrm{ClO}_{4}^{-}(100 \mathrm{mg} / \mathrm{L})$. Perchlorate content in the achira tissues increased with increasing perchlorate level in the wetland system (Table 4). These findings are in line with previous findings for other wetland plants (Seyfferth and Parker 2008).

Perchlorate content in the above-water tissues (aerial stem, leaf, and flower) of achira was much higher than that in the underwater tissues (root and rhizome). The order of perchlorate content in different tissues of achira was: leaf > aerial stem > flower or rhizome > root. Perchlorate content in achira leaf was 2868.51 and 10441.06 $\mathrm{mg} / \mathrm{kg} \mathrm{DW}$ in column $C_{40}$ and $C_{100}$, respectively. In contrast, lower perchlorate content in root was observed, 141.03 and $703.51 \mathrm{mg} / \mathrm{kg} \mathrm{DW}$ in column $C_{40}$ and $C_{100}$, respectively. It is evident that perchlorate mainly accumulated in leaf (more than 55.8\%) rather than in root (less than $0.67 \%$ ). Similar results have been reported in other plants (Tan et al. 2004b).

On the basis of dry weight, perchlorate bio-concentration factor (BCF) of achira leaf was calculated to be 71.71 and 104.41 in column $C_{40}$ and $C_{100}$, respectively (Table 4). The BCF of achira in the present study is close to that of other aquatic plants, such as smart-weed (Polygonum sp.), watercress (Nasturtium sp.), and bulrush (Scirpus sp.) (Tan et al., 2004a, b).

Mass balance analysis

The contribution of each component to the overall $\mathrm{ClO}_{4}^{-}$removal by the wetland system was evaluated by mass balance analysis. The non-volatile $\mathrm{ClO}_{4}{ }^{-}$can be degraded to innocuous $\mathrm{Cl}^{-}$. Assuming steady-state conditions, the following mass balance equation can be derived for perchlorate in the planted wetland columns:

$M_{\text {in }}=M_{\text {out }}+M_{p}+M_{\mathrm{m}}+M_{\mathrm{s}}$

where $M_{\text {in }}$ is total $\mathrm{ClO}_{4}^{-}$input to the wetland system $(\mathrm{g}), \mathrm{M}_{\text {out }}$ is $\mathrm{ClO}_{4}^{-}$output with the effluent from the wetland system $(\mathrm{g}), M_{\mathrm{p}}$ is the part absorbed by the plants $(\mathrm{g}), M_{\mathrm{m}}$ is the part degraded by microbes $(\mathrm{g})$, and $M_{\mathrm{s}}$ is the part adsorbed by the soil and gravels.

As shown in Table 5, less than $6.32 \%$ of $\mathrm{ClO}_{4}{ }^{-}$input was adsorbed by the soil or gravels in any of the treatments, about $5.81-7.34 \%$ was absorbed by achira in the planted columns, and more than $29.39 \%$ was degraded by microbes in any of the treatments. Tan et al. (2004b) reported that $0-14.3 \%$ of initial $\mathrm{ClO}_{4}{ }^{-}$input (32 mg/L) was absorbed by plants, whereas 48.4-99.9\% was biodegraded in planted columns. Nzengung et al. (1999) concluded that phytodegradation contributed to approximately $11 \%$ perchlorate removal in their 26 -day experiment. Previous findings in the literature and our mass data (Table 5) indicated that microbial perchlorate reduction instead of plant uptake plays a major role in perchlorate removal by planted wetland systems.

A significantly higher percentage of the initial $\mathrm{ClO}_{4}^{-}$input was biodegraded in the planted columns than in the unplanted columns. Of the initial $\mathrm{ClO}_{4}{ }^{-}$input, $62.48 \%$ and $43.27 \%$ was biodegraded in the planted $C_{40}$ and $C_{100}$ treatments, respectively. In comparison, $45.90 \%$ and $29.39 \%$ was biodegraded in the unplanted $C_{40}$ and $C_{100}$ columns, respectively. Interestingly, achira greatly increased the proportion of perchlorate being biodegraded, 
indicating that plants play an important role by creating a more favorable environment for microbial growth and activity. In this study, no external carbon was supplied to the wetland columns. Carbon required by the perchlorate-reducing microbes must be self-supplied in the wetland systems. Therefore, it is expected that plant would play a more important role with time in such wetland systems as it provides both habitat and food for the indigenous perchlorate-reducing microorganisms.

Microbial populations in the constructed wetlands

As shown in Table 6, the CFUs of culturable bacteria, fungi, and actinomycetes in rhizosphere decreased with running time of the wetland systems, indicating that microbial growth and reproduction was inhibited by perchlorate and the inhibiting effect became more prominent with time. Sha et al. (2020) also showed that microbial community changed when exposed to perchlorate. For a same perchlorate input level, bacterial, fungal, and actinomycete counts were greater in the planted columns than in the unplanted ones, suggesting that achira helped to improve microbial growth in the wetland systems. Correlation analysis showed that there was a significant positive correlation between perchlorate removal and the microbial counts (Table 9). Additionally, bacteria were prevalent over fungi and actinomycetes in the wetland columns no matter with plants or not. Taken together, contaminants are removed in constructed wetlands under the synergistic action of plant-soil-microorganism, and the symbiont interaction between microorganisms and animals and plants plays a central role (Lee et al. 2009). Microbial species and population in a constructed wetland directly affect the performance of the system.

Effluent $\mathrm{pH}$ value in the constructed wetlands

As shown in Table 7, the differences in effluent $\mathrm{pH}$ between treatments became bigger with running time, especially after the 44th day, when effluent $\mathrm{pH}$ in the planted columns was significantly higher than that in the unplanted columns, suggesting that achira helped to raise $\mathrm{pH}$ value in the wetland systems. Furthermore, in the later periods, the effluent $\mathrm{pH}$ values of the columns, planted or not, were in the order of: $C_{0}>C_{40}>C_{100}$. Correlation analysis showed that there was a significant positive correlation between perchlorate removal and effluent pH (Table 9). Seyfferth et al. (2008a) demonstrated that increasing pH significantly reduced the bioavailability of perchlorate. The $\mathrm{pH}$ variation in the constructed wetland directly affected the perchlorate removal efficiency.

Variation of $\mathrm{NO}_{3}{ }^{-}$in the constructed wetlands

Perchlorate-contaminated water often contains high nitrate $\left(\mathrm{NO}_{3}^{-}\right)$. Studies have demonstrated that simultaneous removal of perchlorate and nitrate is feasible at low nitrate level (Ziv-El and Rittmann 2009; Bardiya and Bae 2011). High nitrate level (above $5 \mathrm{mg} / \mathrm{L}$ ) was found to inhibit $\mathrm{ClO}_{4}{ }^{-}$biodegradation (Tan et al. 2004b). In the present study, $\mathrm{NO}_{3}{ }^{-}$concentration in the effluent decreased gradually with the operation continuing, but increased with increasing $\mathrm{ClO}_{4}{ }^{-}$concentration in both the unplanted and planted columns (Table 8). Effluent $\mathrm{NO}_{3}{ }^{-}$concentration in the planted columns was significantly lower than that in the unplanted columns after 17 days of operation (Table 8). And as shown in Fig.2, for a same perchlorate level in influent, significantly more perchlorate was removed by the planted columns than by the unplanted columns. Thus, the results demonstrated that simultaneous $\mathrm{ClO}_{4}{ }^{-}$and $\mathrm{NO}_{3}{ }^{-}$removal was achieved in the constructed wetlands, and 
achira played an important role in it. Correlation analysis showed that there was a negative, though not significant, correlation $(r=-0.398, P=0.054)$ between $\mathrm{ClO}_{4}{ }^{-}$and $\mathrm{NO}_{3}{ }^{-}$concentrations in effluent. This might be because $\mathrm{ClO}_{4}{ }^{-}$concentration was much higher than $\mathrm{NO}_{3}{ }^{-}$concentration in our wetland systems.

Nitrate is one of the important nutrients for the growth of plants and microorganisms. In higher plants, $\mathrm{ClO}_{4}{ }^{-}$and $\mathrm{NO}_{3}{ }^{-}$may share transporters or transport pathways (Seyfferth et al. 2008b). Some findings have also shown that perchlorate-respiring organisms can grow with nitrate as terminal electron acceptor, and vice versa (Ziv-El and Rittmann 2009). Although interference between $\mathrm{NO}_{3}{ }^{-}$and $\mathrm{ClO}_{4}{ }^{-}$was observed, simultaneous removal was achieved in our wetland system. Therefore, natural achira wetlands can be used to treat perchloratecontaminated nitrate-eutrophic water. However, the design of a constructed wetland system with achira for cotreatment of perchlorate and nitrate should take nitrate concentration into account.

\section{Conclusions}

In summation, we demonstrated the constructed achira wetlands have the potential to treated $\mathrm{ClO}_{4}{ }^{-}$ contaminated wastewaters. Microbial degradation and $\mathrm{pH}$ raise played a major role in overall removal of perchlorate, plant uptake and transformation only contributed to a relatively small portion, but planting achira could greatly improve $\mathrm{ClO}_{4}$ - biodegradation in this wetland system. As plants can provide a continuous carbon source and support medium for microbe growth, plants will play a more important role in long term wetland treatment systems.

\section{Declarations}

\section{Acknowledgments}

The study was supported by the National Natural Science Foundation of China (No. 41877334), Guangdong Basic and Applied Basic Research Foundation (2019A1515012177), the Young Innovative Talents Project in General Colleges and Universities in Guangdong Province (2018 KQNCX147), and Yanling excellent young teacher program of lingnan normal university.

\section{Compliance with ethical standards}

Conflict of interest All authors claim that they do not have any actual or potential conflict of interest including any financial, personal, or other relationships with other people or organizations.

Funding: The study was supported by the National Natural Science Foundation of China (41877334), Guangdong Basic and Applied Basic Research Foundation (2019A1515012177), the Young Innovative Talents Project in General Colleges and Universities in Guangdong Province (2018 KQNCX147), and Yanling excellent young teacher program of lingnan normal university.

Conflicts of interest/Competing interests: We have no known competing financial interests or personal relationships that could have appeared to influence the work reported in this paper.

Ethics approval: Not Applicable. 
Consent to participate: Consent.

Consent for publication: Consent.

Availability of data and material: Not Applicable.

Code availability: Not Applicable.

Authors' contributions: Dongqin Li: Conduct an experiment, Writing- Original draft preparation; Haishuo Gao: Conduct an experiment; Xinyu Du: Visualization, Software; Junhao Qin: Supervision, Methodology; Huashou Li: Data curation; Hongzhi He: Supervision, Conceptualization; Guikui Chen: Writing-Reviewing and Editing, Validation.

\section{References}

1. Abdel-Mohsein HSA, Feng M, Fukuda Y, Tada C (2020) Remarkable Removal of Antibiotic-Resistant Bacteria During Dairy Wastewater Treatment Using Hybrid Full-scale Constructed Wetland. Water Air Soil Pollut 231:397

2. Abt E, Spungen J, Pouillot R, Siebers MG, Wirtz M (2016) Update on dietary intake of perchlorate and iodine from U.S. food and drug administration's total diet study: 2008-2012. Journal of Exposure Science Environmental Epidemiology 00:1-10

3. Bardiya N, Bae J (2011) Dissimilatory perchlorate reduction: A review. Microbiological research 166:237254

4. Bhaskaran K, Vijaya NA, Tumbath S, Babu SL, Gangadharan PVP (2013) Phytoremediation of perchlorate by free floating macrophytes. $\mathrm{J}$ hazardous materials 260:901-906

5. Bilgin M, Şimşek I, Tulun Ş (2014) Treatment of domestic wastewater using a lab-scale activated sludge/vertical flow subsurface constructed wetlands by using Cyperus alternifolius. Ecological engineering 70:362-365

6. Ballesteros F Jr, Vuong TH, Secondes MF, Tuand PD (2016) Removal efficiencies of constructed wetland and efficacy of plant on treating benzene. Sustainable Environment Research 26:93-96

7. Calheiros CSC, Quitério PVB, Silva G, Crispim LFC, Brix H, Moura SC, Castro PML (2012) Use of constructed wetland systems with Arundo and Sarcocornia for polishing high salinity tannery wastewater. Journal of environmental management 95:66-71

8. Calderón R, Godoy F, Escudey M, Palma P (2017) A review of perchlorate $\left(\mathrm{ClO}_{4}{ }^{-}\right)$occurrence in fruits and vegetables. Environmental Monitoring and Assessment 189

9. Choe JK, Mehnert MH, Guest JS, Strathmann TJ, Werth CJ (2013) Comparative assessment of the environmental sustainability of existing and emerging perchlorate treatment technologies for drinking water. Environmental science technology 47:4644-4652

10. de la Varga D, Soto M, Arias CA, van Oirschot D, Kilian R, Pascual A, Álvarez JA (2020) Constructed Wetlands for Industrial Wastewater Treatment and Removal of Nutrients. Waste Manag. DOI:10.4018/9781-5225-1037-6.ch008 
11. Dahan O, Katz I, Avishai L, Ronen Z (2017) Transport and degradation of perchlorate in deep vadose zone: implications from direct observations during bioremediation treatment. Hydrol Earth Syst Sci 21:40114020

12. Fang Q, Xu W, Yan Z, Qian L (2018) Effect of Potassium Chlorate on the Treatment of Domestic Sewage by Achieving Shortcut Nitrification in a Constructed Rapid Infiltration System. International Journal of Environmental Research Public Health 15:670

13. Faulwetter JL, Gagnon V, Sundberg C, Chazarenc F, Burr MD, Brisson J, Camper AK, Stein OR (2009) Microbial processes influencing performance of treatment wetlands: A review. Ecological engineering 35:987-1004

14. He H, Gao H, Chen G, Li H, Lin H, Shu Z (2013) Effects of perchlorate on growth of four wetland plants and its accumulation in plant tissues. Environ Sci Pollut Res 20:7301-7308

15. Her N, Kim J, Yoon Y (2010) Perchlorate in dairy milk and milk-based powdered infant formula in South Korea. Chemosphere 81:732-737

16. Kumarathilaka P, Oze C, Indraratne SP, Vithanage M (2016) Perchlorate as an emerging contaminant in soil, water and food. Chemosphere 150:667-677

17. Kirk AB, Kroll M, Dyke JV, Ohira S, Dias RA, Dasgupta PK (2012) Perchlorate, iodine supplements, iodized salt and breast milk iodine content. Science of the total environment 420:73-78

18. Lee C, Fletcher TD, Sun G (2009) Nitrogen removal in constructed wetland systems. Eng Life Sci 9:11-22

19. Nair RR, Russel JG, Pradeep S, Ajay SV, Krishnakumar B (2020) A novel ex-situ bio-remediation process for perchlorate contaminated soil. Chemosphere 247:125947

20. Nzengung VA, Wang C, Harvey G (1999) Plant-mediated transformation of perchlorate into chloride. Environ Sci Technol 33:1470-1478

21. Sehar S, Nasser HAA (2019) Wastewater treatment of food industries through constructed wetland: a review. Int J Environ Sci Technol 16:6453-6472

22. Sevda S, Sreekishnan TR, Pous N, Puig S, Pant D (2018) Bioelectroremediation of perchlorate and nitrate contaminated water: A review. Biores Technol 255:331-339

23. Seyfferth AL, Parker DR (2008) Uptake and fate of perchlorate in higher plants. Adv Agron 99:101-123

24. Seyfferth AL, Henderson MK, Parker DR (2008a) Effects of common soil anions and pH on the uptake and accumulation of perchlorate in lettuce. Plant Soil 302:139-148

25. Seyfferth AL, Sturchio NC, Parker DR (2008b) Is perchlorate metabolized or re-translocated within Lettuce leaves? A stable-isotope approach. Environ Sci Technol 42:9437-9442

26. Smith EL, Kellman L, Brenton P (2019) Restoration of On-farm Constructed Wetland Systems Used to Treat Agricultural Wastewater. J Agric Sci 11:99

27. Sha J, Wu J, Bi C, Chen C, Su Q, Wang S, Wang C, Zhou Y (2020) Responses of microbial community to different concentration of perchlorate in the Qingyi River. 3 Biotech, 10(1)

28. Shelor CP, Kirk AB, Dasgupta PK, Kroll M, Campbell CA, Choudhary PK (2012) Breastfed infants metabolize perchlorate. Environ Sci Technol 46:5151-5159

29. Sun L, Lua Y, Kronzucker HJ, Shi W (2016) Quantification and enzyme targets of fatty acid amides from duckweed root exudates involved in the stimulation of denitrification. J Plant Physiol 198:81-88 
30. Tan K, Anderson TA, Jones MW, Smith PN, Jackson WA (2004a) Accumulation of perchlorate in aquatic and terrestrial plants at a field scale. J Environ Qual 33:1638

31. Tan K, Jackson WA, Anderson TA, Pardue JH (2004b) Fate of perchlorate-contaminated water in upflow wetlands. Water Res 38:4173-4185

32. U.S. EPA (United State Environmental Protection Agency) (2005) Perchlorate treatment technology update for perchlorate. EPA 542-R-05-015,

33. Wang C, Zhai Y, Zhu Y, Li X, Li C, Zeng G (2017) Concentration and Exposure Evaluation of Perchlorate in Size-Segregated Airborne Particulate Matter from Changsha, China. Water Air Soil Pollut 228:369-379

34. Wu H, Wang X, He X, Zhang S, Liang R, Shen J (2017) Effects of root exudates on denitrifier gene abundance, community structure and activity in a micro-polluted constructed wetland. Science of the total environment 598:697-703

35. Vymazal J, Březinová T (2015) The use of constructed wetlands for removal of pesticides from agricultural runoff and drainage: A review. Environment international 75:11-20

36. Vymazal J (2014) Constructed wetlands for treatment of industrial wastewaters: A review. Ecological engineering 73:724-751

37. Yifru DD, Nzengung VA (2008) Organic carbon biostimulates rapid rhizodegradation of perchlorate. Environmental toxicology chemistry 27:2419-2426

38. Yan J, Wang L, Tsang YF, Qian L, Fu X, Sun Y, Wu P (2020) Conversion of organic carbon from decayed native and invasive plant litter in Jiuduansha wetland and its implications for SOC formation and sequestration. Journal of Soils Sediments volume 20:675-689

39. Zhang T, Wu Q, Sun HW, Rao J, Kannan K (2010) Perchlorate and iodide in whole blood samples from infants, children, and adults in Nanchang, China. Environ Sci Technol 44:6947-6953

40. Ziv-EI MC, Rittmann BE (2009) Systematic evaluation of nitrate and perchlorate bioreduction kinetics in groundwater using a hydrogen-based membrane biofilm reactor. Water Res 43:173-181

\section{Tables}


Table 1 Physical and chemical properties of the soil used in this study

\begin{tabular}{ccccccccccccc}
\hline $\mathrm{pH}$ & $\mathrm{Eh}$ & $\begin{array}{l}\text { Organic } \\
\text { matter } \\
(\mathrm{g} / \mathrm{kg})\end{array}$ & $\begin{array}{l}\text { Total } \\
\text { nitrogen } \\
(\mathrm{g} / \mathrm{kg})\end{array}$ & $\begin{array}{l}\text { Total } \\
\text { phosphorus } \\
(\mathrm{g} / \mathrm{kg})\end{array}$ & $\begin{array}{l}\text { Total } \\
\text { potassium } \\
(\mathrm{g} / \mathrm{kg})\end{array}$ & $\begin{array}{l}\text { Available } \\
\text { nitrogen } \\
(\mathrm{mg} / \mathrm{kg})\end{array}$ & $\begin{array}{l}\text { Available } \\
\text { phosphorus }\end{array}$ & $\begin{array}{l}\text { Available } \\
\text { potassium } \\
(\mathrm{mg} / \mathrm{kg})\end{array}$ & $\begin{array}{c}\mathrm{Cl}^{-} \\
(\mathrm{mg} / \mathrm{kg})\end{array}$ & $\begin{array}{c}\mathrm{ClO}_{3}{ }^{-} \\
(\mathrm{mg} / \mathrm{kg})\end{array}$ \\
\hline 5.94 & 66.4 & 20.92 & 0.932 & 0.954 & 18.67 & 56.41 & 71.91 & 229.96 & 60.82 & n.a. \\
\end{tabular}

Noteøn.a. indicates not detected.

Table 2 The characteristics of the tap water used in this study

\begin{tabular}{|c|c|c|c|c|c|c|c|c|c|c|}
\hline $\mathrm{pH}$ & $\begin{array}{l}\text { Electrical } \\
\text { conductivity } \\
(\mu \mathrm{s} / \mathrm{cm})\end{array}$ & $\begin{array}{l}\text { Total } \\
\text { dissolved } \\
\text { solids } \\
\text { (mg/L口 }\end{array}$ & $\begin{array}{l}\begin{array}{l}\text { Dissolved } \\
\text { oxygen }\end{array} \\
\text { (mg/L口 }\end{array}$ & $\begin{array}{c}\text { Biochemical } \\
\text { oxygen } \\
\text { demand } \\
\text { (mg/L】 }\end{array}$ & $\begin{array}{l}\text { Chemical } \\
\text { oxygen } \\
\text { demand } \\
\text { (mg/Lu }\end{array}$ & $\begin{array}{l}\text { Total } \\
\text { phosphorus } \\
\text { (mg/L) }\end{array}$ & $\begin{array}{l}\text { Total } \\
\text { nitrogen } \\
(\mathrm{mg} / \mathrm{L})\end{array}$ & $\begin{array}{l}\mathrm{Cl}^{-} \\
(\mathrm{mg} / \mathrm{L})\end{array}$ & $\mathrm{ClO}_{3}^{-}(\mathrm{mg} / \mathrm{L})$ & $\mathrm{ClO}_{4}^{-{ }^{-}}(\mathrm{n}$ \\
\hline 6.66 & 146.90 & 75.40 & 5.00 & 0.61 & 12.13 & 0.02 & 0.20 & 12.66 & 1.a. & \\
\hline
\end{tabular}

Table 3 Some growth parameters of achira (Canna indica L.) in the different wetland column

\begin{tabular}{|c|c|c|c|c|c|c|}
\hline \multirow[t]{2}{*}{ Treatment } & \multirow[t]{2}{*}{ Root length (cm) } & \multirow[t]{2}{*}{ Plant height $(\mathrm{cm})$} & \multicolumn{2}{|c|}{ Fresh weight (g /plant) } & \multicolumn{2}{|c|}{ Plant biomass (kg DW /m } \\
\hline & & & Root & Above-water & Root & Above-wate \\
\hline$\overline{C_{0}}$ & $45.87 \pm 3.82 \mathrm{a}$ & $88.27 \pm 0.69 \mathrm{a}$ & $51.80 \pm 2.36 \mathrm{a}$ & $206.59 \pm 4.56 \mathrm{a}$ & $1.87 \pm 0.14 \mathrm{a}$ & $7.28 \pm 0$ \\
\hline$C_{40}$ & $30.87 \pm 2.78 \mathrm{~b}$ & $75.80 \pm 1.31 \mathrm{~b}$ & $39.42 \pm 2.89 \mathrm{~b}$ & $181.63 \pm 6.85 \mathrm{~b}$ & $1.36 \pm 0.11 \mathrm{~b}$ & $6.27 \pm 0.21$ \\
\hline$C_{100}$ & $26.67 \pm 1.32 \mathrm{~b}$ & $64.23 \pm 1.86 \mathrm{c}$ & $38.85 \pm 2.85 \mathrm{~b}$ & $178.11 \pm 7.07 \mathrm{~b}$ & $1.26 \pm 0.08 \mathrm{~b}$ & $6.09 \pm 0$ \\
\hline
\end{tabular}

The data are presented as mean \pm standard error $(n=3)$. Different lowercase letters in a same column indicate signi differences between treatments (Duncan's multiple range tests, $P<0.05$ )

Table 4 Distribution of perchlorate in different tissues of achira (Canna indica L.) at the end c the experiment 


\begin{tabular}{|c|c|c|c|c|c|c|c|c|}
\hline & \multicolumn{2}{|c|}{$\begin{array}{l}\mathrm{ClO}_{4}{ }^{-} \text {content } \\
(\mathrm{mg} / \mathrm{kg} \mathrm{DW}) \\
\end{array}$} & \multicolumn{2}{|c|}{$\begin{array}{l}\text { Bio-concentration factor } \\
\text { (BCF) }\end{array}$} & \multicolumn{2}{|c|}{$\begin{array}{c}\mathrm{ClO}_{4}{ }^{-} \text {accumulation } \\
(\mathrm{mg} / \text { pot DW })\end{array}$} & \multicolumn{2}{|c|}{$\begin{array}{r}\text { Fractio] } \\
\text { (\%) }\end{array}$} \\
\hline & $C_{40}$ & $C_{100}$ & $C_{40}$ & $C_{100}$ & $C_{40}$ & $C_{100}$ & $C_{40}$ & $\bar{C}$ \\
\hline Root & $141.03 \pm 4.98 \mathrm{~d}$ & $703.51 \pm 12.06 \mathrm{~d}$ & 3.53 & 7.04 & 0.34 & 1.78 & 0.41 & $\overline{0}$ \\
\hline Rhizome & $\begin{array}{r}1456.39 \pm 39.00 \\
\mathrm{C}\end{array}$ & $3541.41 \pm 38.58 \mathrm{c}$ & 36.41 & 35.41 & 6.96 & 14.65 & 8.31 & \\
\hline $\begin{array}{l}\text { Aerial } \\
\text { stem }\end{array}$ & $\begin{array}{r}1767.26 \pm 77.40 \\
b\end{array}$ & $\begin{array}{r}5296.25 \pm 181.24 \\
b\end{array}$ & 44.18 & 52.96 & 27.32 & 81.46 & 32.63 & \\
\hline Leaf & $\begin{array}{r}2868.51 \pm 114.45 \\
a\end{array}$ & $\begin{array}{r}10441.06 \pm 631.59 \\
\mathrm{a}\end{array}$ & 71.71 & 104.41 & 46.72 & 162.32 & 55.8 & 6 \\
\hline Flower & $\begin{array}{r}1517.06 \pm 44.07 \\
\mathrm{C}\end{array}$ & $3371.75 \pm 87.61 \mathrm{c}$ & 37.93 & 33.72 & 2.39 & 4.82 & 2.85 & \\
\hline
\end{tabular}

The data are presented as mean \pm standard error $(n=3)$. In a same column, different lowercase letters indicate signi differences between tissues (Duncan's multiple range tests, $P<0.05$ ) .

Bioconcentration factor $(\mathrm{BCF})$ was calculated according to the following equation: $\mathrm{BCF}=\mathrm{Cd} \mathrm{plant}_{\mathrm{p}} / \mathrm{Cd}_{\text {soil }}$

Table 5 Mass balance estimation of perchlorate for different wetland columns

\begin{tabular}{|c|c|c|c|c|c|c|c|c|c|}
\hline \multirow[t]{2}{*}{ Treatment } & \multicolumn{5}{|c|}{$\mathrm{ClO}_{4}{ }^{-}$mass (mg/pot) } & \multicolumn{4}{|c|}{ Percent of initial input (\%) } \\
\hline & Total influent & $\begin{array}{l}\text { Column } \\
\text { effluent }\end{array}$ & $\begin{array}{c}\text { Plant } \\
\text { uptake }\end{array}$ & $\begin{array}{c}\text { Sorption } \\
\text { by } \\
\text { substrate }\end{array}$ & Degradation $^{\mathrm{a}}$ & $\begin{array}{l}\text { Column } \\
\text { effluent }\end{array}$ & $\begin{array}{c}\text { Plant } \\
\text { uptake }\end{array}$ & $\begin{array}{c}\text { Sorption } \\
\text { by } \\
\text { substrate }\end{array}$ & Degradat \\
\hline $\begin{array}{l}\text { Unplanted } \\
C_{40}\end{array}$ & 1440 & 746.58 & - & 32.48 & 660.94 & 51.85 & - & 2.26 & 45.90 \\
\hline $\begin{array}{l}\text { Unplanted } \\
C_{100}\end{array}$ & 3600 & 2314.36 & - & 227.68 & 1057.96 & 64.29 & - & 6.32 & 29.39 \\
\hline $\begin{array}{l}\text { Planted } \\
C_{40}\end{array}$ & 1440 & 456.62 & 83.73 & 0 & 899.65 & 31.71 & 5.81 & 0 & 62.48 \\
\hline $\begin{array}{l}\text { Planted } \\
C_{100}\end{array}$ & 3600 & 1720.22 & 265.03 & 57.20 & 1557.54 & 47.78 & 7.36 & 1.59 & 43.27 \\
\hline
\end{tabular}

Table 6 Microbial number in rhizosphere of different treatments at different times

\begin{tabular}{|c|c|c|c|c|c|c|c|c|c|}
\hline \multirow[t]{2}{*}{ Treatment } & \multicolumn{3}{|c|}{ Fungi $\left(10^{3} \mathrm{cfu} / \mathrm{g} \mathrm{DW}\right)$} & \multicolumn{3}{|c|}{ Bacteria $\left(10^{4} \mathrm{cfu} / \mathrm{g} \mathrm{DW}\right)$} & \multicolumn{3}{|c|}{ Actinomycetes $\left(10^{3} \mathrm{cfu} / \mathrm{g} \mathrm{D}\right.$} \\
\hline & $17^{\text {th }}$ day & $35^{\text {th }}$ day & $53^{\text {th }}$ day & $17^{\text {th }}$ day & $35^{\text {th }}$ day & $53^{\text {th }}$ day & $17^{\text {th }}$ day & $35^{\text {th }}$ day & $53^{\text {th }} d$ \\
\hline Unplanted $C_{0}$ & $2.96 \pm 0.03 \mathrm{~b}$ & $2.55 \pm 0.05 b$ & $1.94 \pm 0.05 \mathrm{~b}$ & $11.51 \pm 0.76 \mathrm{bc}$ & $9.55 \pm 0.79 a b c$ & $9.15 \pm 0.83 a$ & $4.04 \pm 0.27 \mathrm{~b}$ & $4.62 \pm 0.16 \mathrm{c}$ & $2.63 \pm 0$ \\
\hline $\begin{array}{l}\text { Unplanted } \\
C_{40}\end{array}$ & $2.51 \pm 0.01 \mathrm{c}$ & $2.45 \pm 0.12 \mathrm{~b}$ & $1.16 \pm 0.05 \mathrm{e}$ & $9.04 \pm 0.55 \mathrm{~cd}$ & $8.52 \pm 0.36 \mathrm{bc}$ & $5.83 \pm 0.65 b$ & $4.88 \pm 0.47 \mathrm{~b}$ & $4.01 \pm 0.19 \mathrm{~d}$ & 1.63 \\
\hline $\begin{array}{l}\text { Unplanted } \\
C_{100}\end{array}$ & $1.76 \pm 0.05 \mathrm{e}$ & $1.78 \pm 0.17 \mathrm{c}$ & $0.82 \pm 0.04 \mathrm{f}$ & $7.16 \pm 0.71 \mathrm{~d}$ & $5.36 \pm 0.53 \mathrm{~d}$ & $3.83 \pm 0.16 \mathrm{c}$ & $5.23 \pm 0.11 b$ & $2.47 \pm 0.26 \mathrm{e}$ & 0 . \\
\hline Planted $C_{0}$ & $4.11 \pm 0.09 \mathrm{a}$ & $3.21 \pm 0.09 \mathrm{a}$ & $2.60 \pm 0.03 a$ & $26.87 \pm 2.40 \mathrm{a}$ & $11.45 \pm 1.50 \mathrm{a}$ & $9.85 \pm 0.57 a$ & $7.14 \pm 0.22 \mathrm{a}$ & $7.52 \pm 0.22 \mathrm{a}$ & $3.38=$ \\
\hline Planted $C_{40}$ & $2.55 \pm 0.08 \mathrm{c}$ & $2.47 \pm 0.13 b$ & $1.97 \pm 0.03 \mathrm{~b}$ & $13.12 \pm 1.57 \mathrm{bc}$ & $10.59 \pm 0.74 \mathrm{ab}$ & $7.02 \pm 0.79 b$ & $6.86 \pm 0.38 \mathrm{a}$ & $5.74 \pm 0.07 \mathrm{~b}$ & $2.96 \pm 0$ \\
\hline Planted $C_{100}$ & $2.26 \pm 0.12 \mathrm{~d}$ & $1.97 \pm 0.08 \mathrm{c}$ & $1.46 \pm 0.08 \mathrm{c}$ & $13.69 \pm 0.58 b$ & $7.40 \pm 0.91 \mathrm{bcd}$ & $5.74 \pm 0.41 \mathrm{~b}$ & $4.12 \pm 0.73 b$ & $3.59 \pm 0.20 \mathrm{~d}$ & $2.24 \pm 0$ \\
\hline
\end{tabular}


Table 7 Effluent pH of every period

\begin{tabular}{lcccccc}
\hline \multicolumn{1}{c}{ Treatment } & $8^{\text {th }}$ day & $17^{\text {th }}$ day & $26^{\text {th }}$ day & $35^{\text {th }}$ day & $44^{\text {th }}$ day & $53^{\text {th }}$ day \\
\hline Unplanted $C_{0}$ & $7.43 \pm 0.02 \mathrm{a}$ & $7.46 \pm 0.06 \mathrm{a}$ & $7.33 \pm 0.04 \mathrm{ab}$ & $7.34 \pm 0.03 \mathrm{c}$ & $7.35 \pm 0.04 \mathrm{bc}$ & $7.38 \pm 0.01 \mathrm{c}$ \\
Unplanted $C_{40}$ & $7.47 \pm 0.15 \mathrm{a}$ & $7.29 \pm 0.05 \mathrm{~b}$ & $7.24 \pm 0.13 \mathrm{~b}$ & $7.30 \pm 0.03 \mathrm{c}$ & $7.29 \pm 0.04 \mathrm{c}$ & $7.37 \pm 0.07 \mathrm{c}$ \\
Unplanted $C_{100}$ & $7.58 \pm 0.09 \mathrm{a}$ & $7.04 \pm 0.01 \mathrm{c}$ & $7.01 \pm 0.01 \mathrm{c}$ & $7.08 \pm 0.02 \mathrm{~d}$ & $7.10 \pm 0.01 \mathrm{~d}$ & $7.02 \pm 0.06 \mathrm{~d}$ \\
Planted $C_{0}$ & $7.51 \pm 0.21 \mathrm{a}$ & $7.55 \pm 0.02 \mathrm{a}$ & $7.55 \pm 0.03 \mathrm{a}$ & $7.72 \pm 0.06 \mathrm{a}$ & $7.73 \pm 0.03 \mathrm{a}$ & $7.83 \pm 0.04 \mathrm{a}$ \\
Planted $C_{40}$ & $7.63 \pm 0.10 \mathrm{a}$ & $7.46 \pm 0.01 \mathrm{a}$ & $7.56 \pm 0.02 \mathrm{a}$ & $7.58 \pm 0.02 \mathrm{~b}$ & $7.66 \pm 0.01 \mathrm{a}$ & $7.73 \pm 0.09 \mathrm{ab}$ \\
Planted $C_{100}$ & $7.61 \pm 0.02 \mathrm{a}$ & $7.24 \pm 0.08 \mathrm{~b}$ & $7.23 \pm 0.09 \mathrm{~b}$ & $7.35 \pm 0.01 \mathrm{c}$ & $7.42 \pm 0.02 \mathrm{~b}$ & $7.56 \pm 0.03 \mathrm{~b}$ \\
\hline
\end{tabular}

Table 8 The concentration of $\mathrm{NO}_{3}{ }^{-}$in effluent of every period (mg/L)

\begin{tabular}{lccccccc}
\hline ent & $8^{\text {th }}$ day & $17^{\text {th }}$ day & $26^{\text {th }}$ day & $35^{\text {th }}$ day & $44^{\text {th }}$ day & $53^{\text {th }}$ day & average \\
\hline ited $C_{0}$ & $3.58 \pm 0.75 \mathrm{c}$ & $10.48 \pm 0.34 \mathrm{~b}$ & $5.47 \pm 1.52 \mathrm{a}$ & $4.19 \pm 0.23 \mathrm{c}$ & $2.35 \pm 0.04 \mathrm{c}$ & $1.15 \pm 0.05 \mathrm{~b}$ & $4.54 \pm 0.76$ \\
Ited $C_{40}$ & $1.81 \pm 0.03 \mathrm{~cd}$ & $3.07 \pm 0.06 \mathrm{e}$ & $3.09 \pm 0.10 \mathrm{ab}$ & $5.35 \pm 0.39 \mathrm{~b}$ & $4.95 \pm 0.38 \mathrm{~b}$ & $1.72 \pm 0.01 \mathrm{~b}$ & $3.34 \pm 0.35$ \\
ted $C_{100}$ & $3.26 \pm 0.48 \mathrm{c}$ & $16.81 \pm 0.04 \mathrm{a}$ & $6.04 \pm 1.66 \mathrm{a}$ & $11.89 \pm 0.19 \mathrm{a}$ & $8.51 \pm 0.03 \mathrm{a}$ & $4.19 \pm 0.66 \mathrm{a}$ & $8.45 \pm 1.17$ \\
l $C_{0}$ & $7.87 \pm 1.02 \mathrm{~b}$ & $4.84 \pm 0.06 \mathrm{~d}$ & $0.99 \pm 0.44 \mathrm{~b}$ & $0.60 \pm 0.14 \mathrm{~d}$ & $0.48 \pm 0.01 \mathrm{~d}$ & $0.80 \pm 0.01 \mathrm{~b}$ & $2.60 \pm 0.70$ \\
в $C_{40}$ & $1.20 \pm 0.64 \mathrm{~d}$ & $7.16 \pm 0.70 \mathrm{c}$ & $1.34 \pm 0.62 \mathrm{~b}$ & $0.96 \pm 0.08 \mathrm{~d}$ & $0.44 \pm 0.02 \mathrm{~d}$ & $0.83 \pm 0.19 \mathrm{~b}$ & $1.99 \pm 0.59$ \\
z $C_{100}$ & $15.68 \pm 0.15 \mathrm{a}$ & $8.02 \pm 0.06 \mathrm{c}$ & $3.24 \pm 0.12 \mathrm{ab}$ & $1.14 \pm 0.11 \mathrm{~d}$ & $0.47 \pm 0.02 \mathrm{~d}$ & $1.20 \pm 0.19 \mathrm{~b}$ & $4.96 \pm 1.31$
\end{tabular}

Table 9 Correlation coefficients between $\mathrm{ClO}_{4}{ }^{-}$removal and some wetland properties

\begin{tabular}{|c|c|c|c|c|c|c|}
\hline & $\mathrm{ClO}_{4}{ }^{-}$removal & $\mathrm{pH}$ & $\mathrm{NO}_{3}{ }^{-}$ & Fungus & Bacteria & Actinomycetes \\
\hline $\mathrm{ClO}_{4}^{-}$removal & 1.000 & & & & & \\
\hline $\mathrm{pH}$ & $0.803^{* *}$ & 1.000 & & & & \\
\hline $\mathrm{NO}_{3}^{-}$ & -0.398 & $-0.465 *$ & 1.000 & & & \\
\hline Fungus & $0.833^{* *}$ & 0.508 & -0.204 & 1.000 & & \\
\hline Bacteria & $0.683^{*}$ & $0.666^{*}$ & 0.195 & $0.801 * *$ & 1.000 & \\
\hline Actinomycetes & $0.817 * *$ & 0.648* & -0.265 & $0.847^{* *}$ & $0.797 * *$ & 1.000 \\
\hline
\end{tabular}

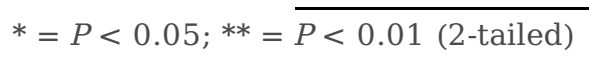

Figures 

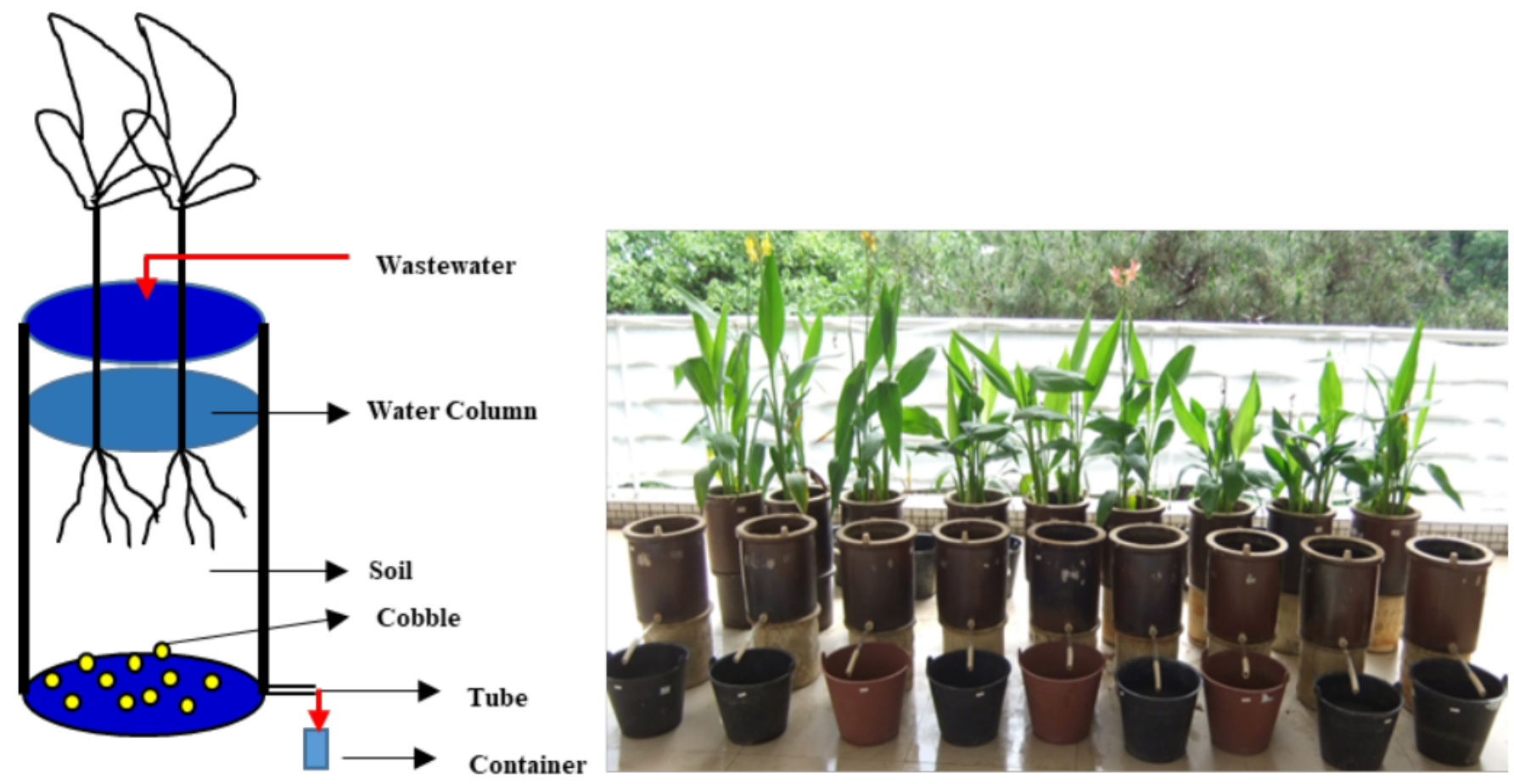

\section{Figure 1}

Schematic diagram showing a simulated wetland vegetated with achira (Canna indica L.) 
Fig.2

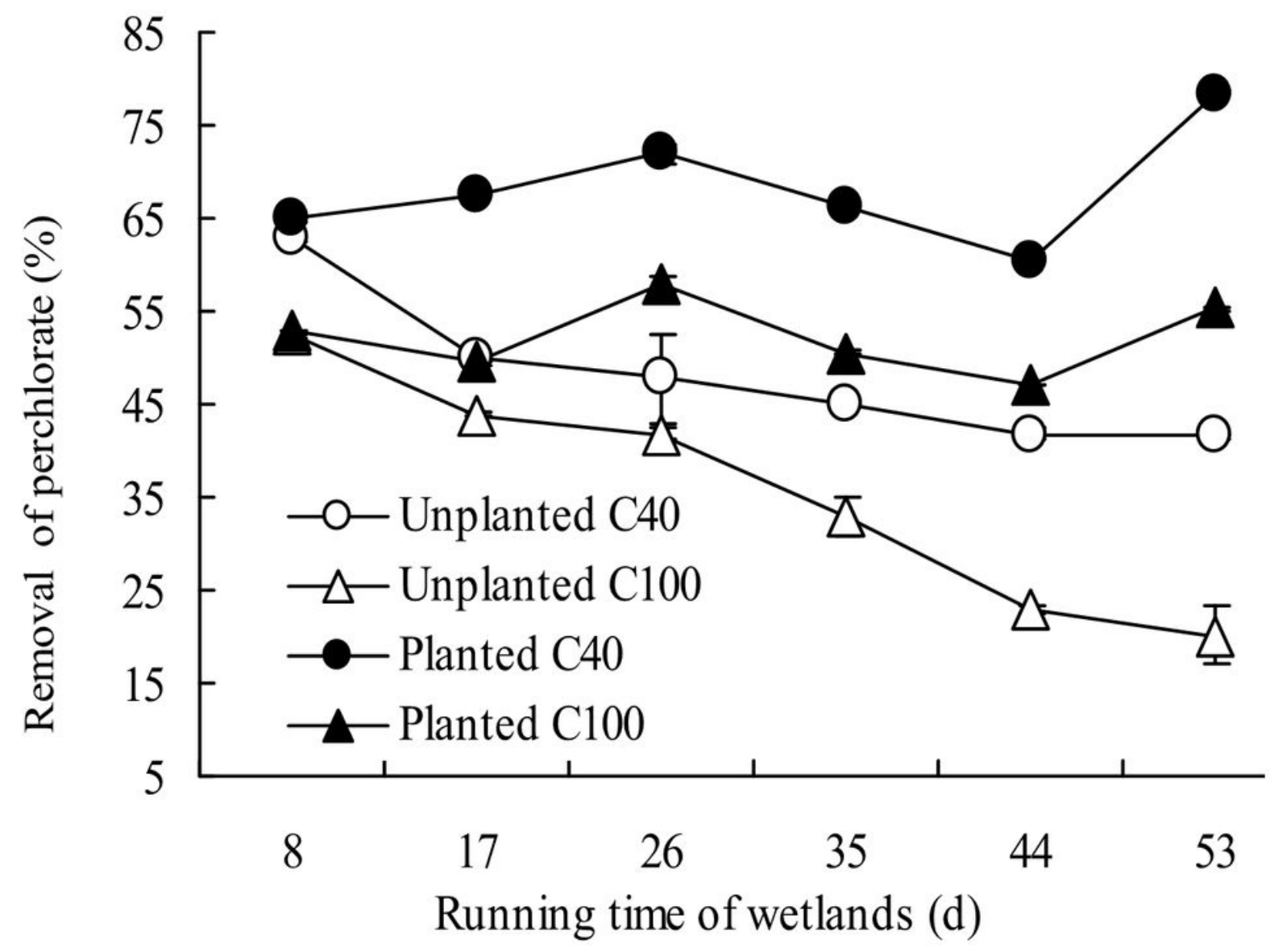

Figure 2

Percent removal of perchlorate in different constructed wetland columns. 